\title{
AN INVESTIGATION OF THE RELATIONSHIP BETWEEN LAND SURFACE TEMPERATURES AND BIOPHYSICAL INDICES RETRIEVED FROM LANDSAT TM IN AFYONKARAHISAR (TURKEY)
}

\author{
Murat Uysal, Nizar Polat
}

Original scientific paper

This study investigates the land surface heat formation in Afyonkarahisar based on the relationship between LST and surface biophysical parameters (NDVI, NDBI and NDWI) for Afyonkarahisar provinces for the years 1987 and 2011. Landsat 5 TM satellite images are used to retrieve NDVI, NDBI and NDWI and surface temperature. While the calculated mean surface temperature for the year 1987 is $27,75^{\circ} \mathrm{C}$ for the city and $27,04{ }^{\circ} \mathrm{C}$ for the urban area, the calculated mean surface temperature of the year 2011 is $25,98{ }^{\circ} \mathrm{C}$ for the city and $24,81{ }^{\circ} \mathrm{C}$ for the urban area. Based on the analysis of these indices, a slight urban heat sink (UHS) was observed in Afyonkarahisar due to the small size of the city. This study shows that the main causes of the urban heat sink (UHS) in the study area are the natural occurrence including the three very high volcanic rocky hills in the city and geothermal water springs around the city.

Keywords: land surface temperature; Landsat; natural formation; normalized difference building index; normalized difference vegetation index; normalized difference water index; urban heat sink

\section{Ispitivanje odnosa između temperatura na površini zemlje i biofizičkih pokazatelja dobivenih zemljinim satelitom Landsat TM u Afyonkarahisaru (Turska)}

U radu se istražuje stvaranje topline na površini zemlje u Afyonkarahisaru zasnovano na odnosu između LST i biofizičkih parametara površine (NDVI, NDBI i NDWI) na području Afyonkarahisaru za 1987. i 2011. Za dobivanje NDVI, NDBI i NDWI i temperature površine korištene su satelitske slike Landsata $5 \mathrm{TM}$. Dok je proračunata srednja temperature površine u 1987 . iznosila $27,75^{\circ} \mathrm{C}$ u gradu i $27,04{ }^{\circ} \mathrm{C} \mathrm{u}$ urbanom području, srednja temperature površine u 2011. je $25,98{ }^{\circ} \mathrm{C}$ u gradu i $24,81{ }^{\circ} \mathrm{C}$ u urbanom području. Analizom ovih podataka u Afyonkarahisaru zapažen je slabi urbani pad topline (UHS) zbog male veličine grada. U radu je pokazano da su glavni uzroci urbanog smanjenja topline (UHS) u proučavanom području prirodnog porijekla, uključujući tri vrlo visoka kamena brijega vulkanskog porijekla u gradu i geotermalne izvore vode oko grada.

Ključne riječi: normalizirani indeks razlike u vegetaciji; normalizirani indeks razlike u vodama; normalizirani indeks razlike u izgrađenosti; površinska temperature zemlje; prirodna tvorevina; urbani pad topline; Zemljin satelit;

\section{Introduction}

People's desire to live together was the main reason for the development of big cities. Today more than $50 \%$ of the world's population live in urban areas, a percentage which continues to increase, particularly in developing countries [1]. Urbanization is a process that vastly influences biodiversity, ecosystems, and territorial climates. These developments in industry and technology including the high-rise establishment of living areas with a large population, adversely affect nature and climates. Rapid urbanization causes a drastic decreasing green land and a rapid increase in the reinforced concrete area [2]. Additionally, the city's surfaces are characterized by low albedo, high impermeability and favourable thermal properties for energy storage and heat release [3]. Because of this transformation, the core of the city generally becomes warmer than its surrounding areas. This effect is directly proportional to population growth and an increase in urbanization. It must be mentioned that the exchanging natural surface of earth with the artificial elements ends up in ecological changes that have a serious impact on the living standards and quality of cities [4].

It is well known that urbanization can have significant effects on local weather and climate [5]. One of the most significant of these effects is called an Urban Heat Island (UHI) which can be defined as a circumstance occurring when the urban area is warmer than the rural areas surrounding it. This effect was first described by
Luke Howard in the early 1830s [6, 7]. The opposite phenomenon is called an Urban Heat Sink (UHS) and means that the temperature of the urban area is colder than the surrounding rural area [8]. An UHS generally occurs during the early morning in urban areas surrounded by infrequently vegetated surfaces, and has been monitored in cities with mild, tropical, semi-arid, and arid $[9 \div 12]$.

The existence of a UHI or UHS is very harmful to the health of people living in a city [8]. An urban heat island can impact local weather and climates, alter local wind patterns, spur the development of clouds and fog, increase the number of lightning events, and influence the rates of precipitation [13]. Furthermore, the poor air quality and energy usage for cooling can cause especially respiratory illnesses such as asthma. The urban heat island has relations with multiple factors such as air pollution, increase in the temperature due to production activities, high floor area ratio, unreasonable vegetation, and water distribution [14]. For this reason, the detection of UHI, the investigation of affecting factors and analysing the results are very important for the planning of future cities and the expansion of existing cities. It also has direct impacts on the protection of natural areas, water resources, energy-saving, and good living quality in city life. To monitor the occurrence and development of the UHI, the scientists have carried out various studies, such as NOAA AVHRR data usage [15], LANDSAT TM 5 usage [16], different soft wares [17] and global effects [18]. 
Urban Heat formation can be determined in two ways. The first way is the traditional one that is measuring air temperature in the city. Nowadays, this method is not used widely. As the second way, the studies of determination of the urban heat formation are realized based on remotely sensed thermal infrared images [18]. These studies have concluded with UHI and less frequently UHS $[19 \div 23]$. Although the temperature derived from satellite data is instantaneous (image captured time) temperature during the day, it is still very important because it is easy to obtain information about entire surface of interested area by using satellite data [24]. In the earlier years, NOAA-AVHHR data and recently MODIS, LANDSAT and ASTER data have been used for deriving land surface biophysical parameters such as vegetation abundances, built up indices and land surface temperature $(L S T)$ that are good indicators of situation of urban ecosystem to investigate the urban heat formation $[25,15,26,16,27,28]$.

Some studies related to urban climate change have examined the relationship between the Land Surface Temperature $(L S T)$ and urbanization in order to analyse surface UHI $[29 \div 32]$. These previous studies have shown that higher urban intensity and imperviousness usually cause higher land surface temperature $[32,29]$. Basically, urban heat formation appears in the spatial distribution of $L S T$ which is affected by surface heat fluxes and urbanization [17]. So, $L S T$ is the primary key for determining UHI and UHS. The temporal resolution of the data is also important because the $L S T$ can change with respect to the time of the day, day-time and nighttime and the season.

This study examines the relationship of urban heat formation and biophysical parameters generated using Landsat images for Afyonkarahisar City. In particular, it differs from the previously mentioned studies in terms of investigating how some natural formations such as high rocky hills and geothermal spring water that are not being included in the calculation of $L S T$ and other indices, affect the urban heat formation.

\section{Study area}

Afyonkarahisar is located in mountainous countryside inland from the Aegean coast in the southwestern Anatolia region of Turkey $\left(38^{\circ} 14^{\prime} \mathrm{N}\right.$ $35^{\circ} 50^{\prime}$ E). Its surface area is $13927 \mathrm{~km}^{2}$ and the population is 186991 as of 2013 census. It is on a very busy route that comes from Central and Eastern parts of Anatolia to the west Anatolia region and it passes Afyonkarahisar. It is also an important railroad junction between Izmir, Konya, Ankara and Istanbul. There are geothermal springs in the region of the city with wellknown geothermal tourism. As shown in Fig. 1 the three volcanic rocky hills in the city act as skyscrapers with a height over $100 \mathrm{~m}$. The historical castle of the city was built on one of these hills and stands at 266 meters tall.

Afyonkarahisar has a continental and semi-arid climate with cold and snowy winters and hot-dry summers. Rainfall occurs mostly during the spring and autumn. The annual average temperature is $11,2{ }^{\circ} \mathrm{C}$, the average rainfall is $407 \mathrm{~mm}$ and elevation is $1013 \mathrm{~m}$.

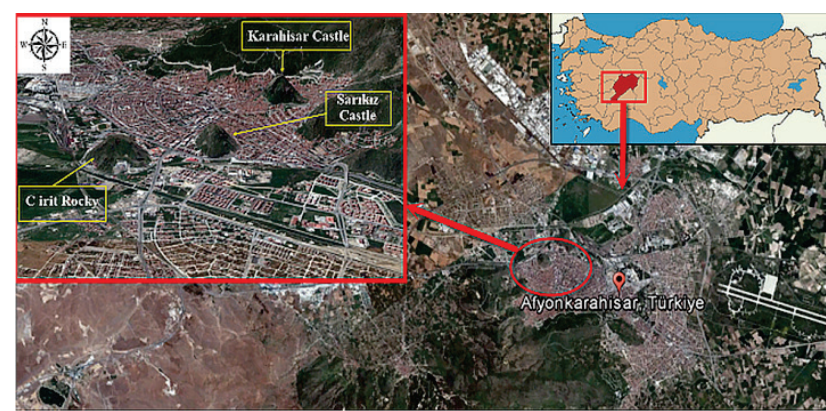

Figure 1 Study area and rocky hills in Afyonkarahisar city

\section{Material and methods}

Two Landsat 5 TM satellite images at the dates of 1987 and 2011 are used in the study for retrieving indices. Reasons to prefer Landsat data are high resolution (120 $\mathrm{m})$ and free download availability of website of US Geological Survey (USGS). Meteorological data are obtained from two weather stations.

\subsection{LST Calculation}

In order to obtain the LST, the thermal band of Landsat TM satellite imagery that is sensitive to infrared regions of the spectrum is used. Converting pixel values (DN) of the thermal band to spectral radiance values (brightness temperature) is an essential step for obtaining LST. For this process, the Eq. (1) is supplied by the Landsat user's hand book.

$L_{\lambda}=L_{\min }+\frac{L_{\max }-L_{\min }}{Q_{\text {calmax }}} \cdot Q_{\text {calmin }} \cdot$

In this equation:

$L_{\lambda}$ is spectral radiance conversion from pixel values (DN), $L_{\max }$ is spectral radiance scaled to $Q_{\text {calmax }}$ in $\mathrm{W}\left(\mathrm{m}^{2} \cdot \mathrm{sr} \cdot \mu \mathrm{m}\right)$, $L_{\min }$ is spectral radiance scaled to $Q_{\text {calmin }}$ in $\mathrm{W}\left(\mathrm{m}^{2} \cdot \mathrm{sr} \cdot \mu \mathrm{m}\right)$, $Q_{\text {calmax }}$ is maximum quantized calibrated pixel value (relevant to $L_{\max }$ ) in $\mathrm{DN}=255$, and

$Q_{\text {calmin }}$ is minimum quantized calibrated pixel value (relevant to $L_{\min }$ ) in $\mathrm{DN}=1$

The calculated $L_{\lambda}$ spectral radiance used converts to radiant temperature (Kelvin) values using Plank formula displayed in Eq. (2).

$$
T R=\frac{K_{2}}{\ln \left(\frac{K_{1}}{L}+1\right)} .
$$

$K_{1}$ and $K_{2}$ are the calibration constants obtained from the Landsat data user's manual and $L_{\lambda}$ is the spectral radiance (brightness temperature) calculated from Eq. (1). Finally, in order to calculate the land surface temperature (LST) described as a Kinetic temperature (Celsius), the radiant values of temperature are used in the Eq. (3).

$$
L S T=\frac{T R}{1+\left(\lambda+\left(\frac{T R}{\rho}\right) \cdot \ln \varepsilon\right)} .
$$


All processes and calculations were made in Envi IDL for all pixels.

\subsection{NDBI Calculation}

The differences in UHS patterns can be associated with many factors including changes in land use, urban surface geometry, seasonal variations, climatic and meteorological conditions, and other conditions [ $33 \div 35]$. In this section, the mathematical equations of Normalized Difference Built-up Index (NDBI) and other indices are done in order to provide more extensive building information. $N D B I$ is one of the widely used indices to extract the built-up land from the urban area [36].

The equation for $N D B I$ is as follows:

$N D B I=\frac{M I R-N I R}{M I R+N I R}$.

This index was created on the assumption that the reflectivity of urban buildings in the fifth band is higher than in the fourth band. The differences of the reflectivity between these two bands are small and many other features have similar spectral attributes to the buildings. Therefore, the built-up land cannot be extracted exactly only using $N D B I$ [36].The processes were performed for the years of 1987 and 2011.

\subsection{NDVI and NDWI calculation}

The Normalized Difference Indexes are commonly used to characterize the land cover types and in this study they were used to evaluate the relationship between land cover types and heat formation. Normalized Difference Water Index $(N D W I)$ is calculated according to Eq. (5) and Normalized Difference Vegetation Index (NDVI) is defined by Eq. (6).

$$
\begin{aligned}
& N D W I=\frac{N I R-M I R}{N I R+M I R} . \\
& N D V I=\frac{T M 4-T M 3}{T M 4+T M 3} .
\end{aligned}
$$

\section{Discussion}

The generated normalized index images are compatible with each other. The correlations between $L S T$ and other indices are calculated and given below for both years. A sample set was chosen and was used to calculate all biophysical indices and correlation for each year with $95 \%$ confidence.

The images of $L S T$ and biophysical parameters of NDVI, NDBI and NDWI for the year of 1987 are shown in Fig. 2.

As shown in Fig. 2, the biophysical indices have a high correlation. Especially some vegetated areas marked with red circles and the airport in blue rectangle indicate a good match. The correlation values of indices support the images. For instance, the vegetated areas can be detected both in NDWI and NDVI images with a high positive correlation by means of similar brightness values. On the other hand the correlation between $N D W I$ and $N D B I$ is negative (Tab. 1).

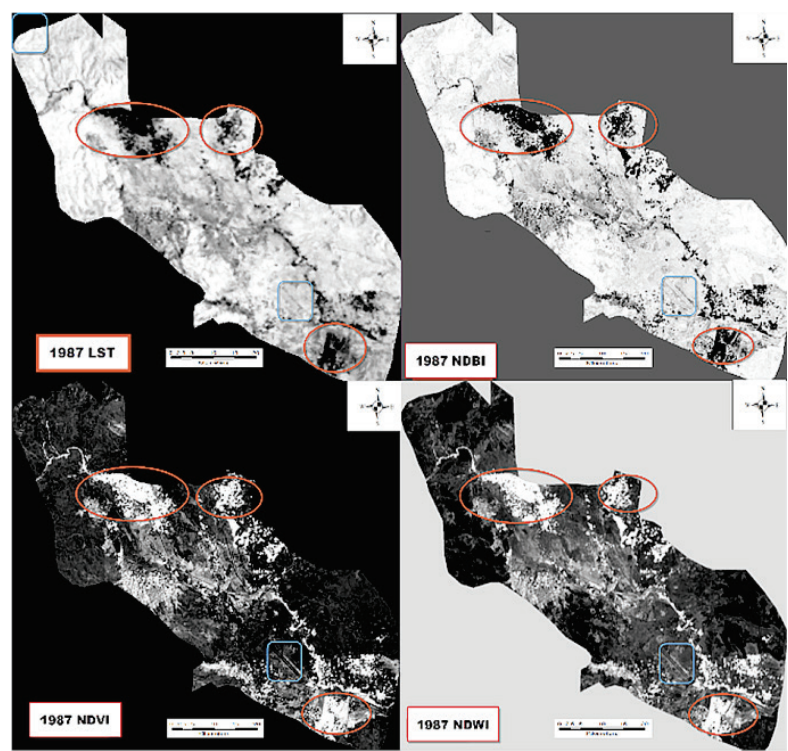

Figure 2 The images of biophysical indices for 1987

Table1 Correlations of biophysical indices for 1987

\begin{tabular}{|c|c|c|c|c|}
\hline Indices & $L S T$ & NDVI & NDBI & NDWI \\
\hline$L S T$ & 1 & $-0,9993$ & $-0,8948$ & $-0,9708$ \\
\hline$N D V I$ & $-0,9993$ & 1 & $-0,9720$ & 0,9720 \\
\hline$N D B I$ & $-0,8948$ & $-0,9720$ & 1 & -1 \\
\hline$N D W I$ & $-0,9708$ & 0,9720 & -1 & 1 \\
\hline
\end{tabular}

The images of $L S T$ and biophysical parameters of NDVI, NDBI and NDWI for the year 2011 are shown in Fig. 3.

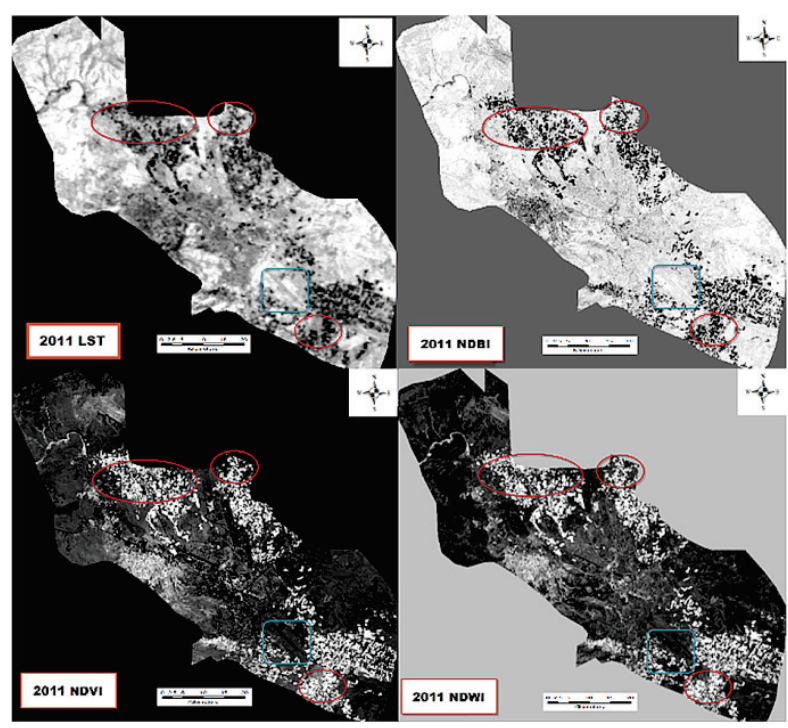

Figure 3 Relations between biophysical indices for 2011

Table 2 Correlation of biophysical indices for 2011

\begin{tabular}{|c|c|c|c|c|}
\hline Indices & $L S T$ & $N D V I$ & $N D B I$ & $N D W I$ \\
\hline$L S T$ & 1 & $-0,9978$ & $-0,8948$ & $-0,8948$ \\
\hline$N D V I$ & $-0,9978$ & 1 & $-0,8993$ & 0,8993 \\
\hline$N D B I$ & $-0,8948$ & $-0,8993$ & 1 & -1 \\
\hline$N D W I$ & $-0,8948$ & 0,8993 & -1 & 1 \\
\hline
\end{tabular}

The same as the outcomes of 1987, the conclusions of 2011 have o good harmony too (Fig. 3). The biophysical indices images of vegetated areas marked with red circles 
and the airport in blue rectangle indicate a nice match. The correlation values of indices in Tab. 2 support the images.

Examining the LST images shown in Fig. 4 and Fig. 5 , it is obvious that the vegetated areas in 2011 increased but more irregularly distributed. The highest temperature values of both years are located at the geothermal spring areas.

The unclassified and classified $L S T$ images and the table of minimum mean and maximum LST values in Celsius $\left({ }^{\circ} \mathrm{C}\right)$ of both years are given below:

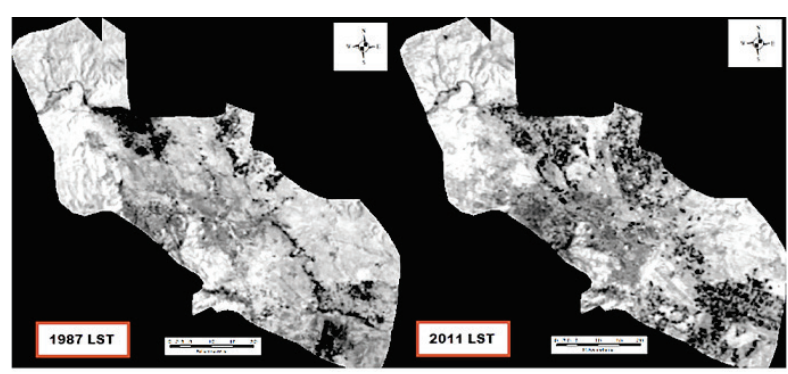

Figure 4 Unclassified LST images of 1987 and 2011

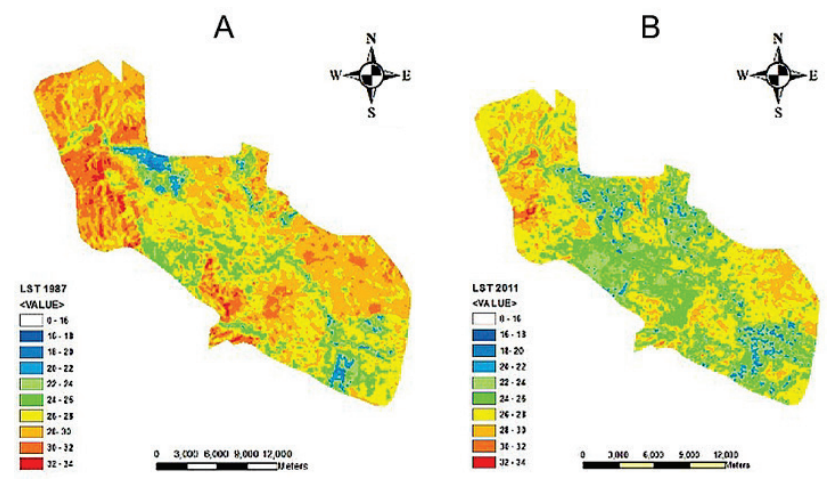

Figure 5 Classified LST images of 1987(A) and 2011(B)

According to Tab. 3, the LST values average between $24 \div 28{ }^{\circ} \mathrm{C}$ for both years. The minimum, maximum temperature values decreased by approximately $1{ }^{\circ} \mathrm{C}$ and the mean was $1,7{ }^{\circ} \mathrm{C}$ at urban and its surrounding area between the 1987 and 2011 .

Table 3 Minimum, mean and maximum surface temperature values for

\begin{tabular}{|c|c|c|c|}
\hline Year & Min & Mean & Max \\
\hline $\begin{array}{c}1987 \text { (urban and } \\
\text { surrounding area) }\end{array}$ & 19,0331 & 27,7555 & 33,7611 \\
\hline $\begin{array}{c}2011 \text { (urban and } \\
\text { surrounding area) }\end{array}$ & 18,4409 & 25,9837 & 33,2353 \\
\hline 1987 (urban area) & 22,5253 & 27,0361 & 32,1772 \\
\hline 2011 (urban area) & 19,3281 & 24,8123 & 29,4939 \\
\hline
\end{tabular}

When only the urban area is considered, it is observed that the difference in temperature was around $3{ }^{\circ} \mathrm{C}$. The $N D V I$ and NDWI indices have a good match with each other. Temperature decreased where the plant density or the amount of water increased and vice versa. Moreover, increasing build up area causes a rise in temperature. The rocky hills cause shadows in the city. The surface temperature values are decreasing due to these wide shadow areas. On the other hand, the surface temperatures of the rural area at northwest of the city have higher values due to the geothermal spring areas.

\section{Conclusion}

In this study, the monitoring of urban heat formation was performed by retrieving $L S T$ from Landsat TM satellite images. The generated $L S T$ images were compared with the observed meteorological temperature values. The obtained $L S T$ values agree with the observed meteorological data and also show similar values in the study area.

Based on the analysis of the obtained $L S T$ values, an urban heat sink (UHS) formation is occurring in Afyonkarahisar, the opposite of the expected urban heat island (UHI). Several reasons for this urban heat sink (UHS) formation can be indicated. First, Afyonkarahisar has several rocky hills approximately $200 \mathrm{~m}$ high and act similarly to high-rise buildings to create conditions common in heat sink formation areas. Secondly, the time the images were captured has impacted the obtained LST data because the satellite passes Afyonkarahisar early in the morning while the shadow of the hills still falls on the city. Finally, there are geothermal springs in the area with temperatures higher than $60{ }^{\circ} \mathrm{C}$. This leads rural areas to be warmer than the urban area. Some controlling processes were instituted to support the reliability of the study. For example, the measured $L S T$ value of the hill tops has higher temperature in the city because they are illuminated by sun earlier while the areas in shadow behind the hills are cooler. Also, the LST value of a cement factory (mean of two years $29,78{ }^{\circ} \mathrm{C}$ ) is verified by meteorological data. The active touristic geothermal spring areas, North-West of the city, proved these as it had the highest temperature in the study area.

In conclusion, it can be said that the obtained LST and biophysical indices are correlated since, naturally, the $L S T$ values are lower in water and vegetated areas than in built up areas for Afyonkarahisar. The LST images show that the temperature of the rural areas is higher than the urban areas thus can be called an urban heat sink (UHS). This study illustrates that natural formations such as rocky hills and geothermal springs have direct impacts on the LST data and lead to the occurrence of an urban heat sink (UHS) in the Afyonkarahisar study area.

\section{References}

[1] United Nations. World Urbanization Prospects the 2011 Revision. Department of Economic and Social Affairs, Population Division. NewYork, 2011.

[2] Guo, Z.; Wanga, S. D.; Chengc, M. M.; Shub, Y. Assess the effect of different degrees of urbanization on land surface temperature using remote sensing images. // Procedia Environmental Science. 13, (2012), pp. 935-942.

[3] Pena, M. A. Relationship between remotely sensed surface parameters associated with urban heat sink formation in Santiago, Chile. // İnternational Journal of Remote Sensing. 29, (2008), pp. 4385-4404.

[4] Yang, L.; Xian, G.; Klaver, J. M.; Deal, B. Urban landcover change detection through sub-pixel imperviousness mapping using remotely sensed data. // Photogrametric engineering and remote sensing. 69, (2003), pp. 1003-1010.

[5] Landsberg, H. E. The Urban Climate. Academic Press: New York, NY, USA. 1981

[6] Howard, L. The Climate of London Volume 2. London Harvey and Dorton: London, UK. 1833. 
[7] Li, H.; Wang, Y.; Shen, X.; Song, Y. Landscape pattern analysis along an urban-rural gradient in Shanghai metropolitan region. // Acta Ecologica Sinica. 24, 9(2004), pp. 1973-1980.

[8] Cai, G.; Du, M. Relationship between thermal inertia and urban heat sink in Beijing derived from satellite images. // Urban Remote Sensing Joint Event. (2009).

[9] Nichole, J. E. High resolution surface temperature patterns related to urban morphology in a tropical city: a satellitebased study. // Journal of Applied Meteorology. 35, (1996), pp. 135-146.

[10] Nichole, J. E. GIS and remote sensing in urban heat islands in the third world. New York: Taylor \& Francis. 2003.

[11] Lougeay, R.; Brazel, A.; Hubble, M. Monitoring intraurban temperature patterns and associated land cover in Phoenix, Arizona using Landsat thermal data. // Geocarto International. 11, (1996), pp. 79-90.

[12] Carnahan, W. H.; Larson, R. C. An analysis of an urban heat sink. // Remote Sensing of Environment. 33, (1990), pp. 65-71.

[13] Liu, L.; Zhang, Y. Urban heat island analysis using the Landsat TM data and ASTER data: a case study in Hong Kong. // Remote Sensing. 3, (2011), pp. 1535-1552.

[14] Hualang, H.; Yunhao, C.; Adu, G. Advances in the application of remotely sensed data to the study of urban heat island // Remote Sensing for Land \& Resource. 3, (2005), pp. 5-13

[15] Gallo, K. P.; McNab, A. L.; Karl T. R.; Brown, J. F.; Hood, J. J.; Tarpley, J. D. The use of NOAA AVHRR data for assessment of urban heat island effect. // Journal of Applied Meteorology. 32, (1993), pp. 899-908.

[16] Sobrino, J. A.; Jiménez-Muoz, J. C.; Paolini, L. Land surface temperature retrieval from LANDSAT TM 5. // Remote Sensing Environment. 90, (2004), pp. 434-446.

[17] Sun, Q.; Tan, J.; Xu, Y. An ERDAS image processing method for retrieving LST and Describing Urban heat Evolution: A case study in Pearl River Delta Region in South China. // Environ. Earth Sci. 59, (2010), pp. 10471055.

[18] Voogt, J. A. Urban Heat Island.Causes and Consequences of Global environmental change, Chichester: John Wiley \& Sons, Ltd. 2003.

[19] Oke, T. R. Boundary Layer Climates ( $2^{\text {nd }}$ Ed.). Taylor \& Francis e- Library 2009.

[20] Stone, B.; Rodgers, M. Urban form and thermal efficiency: how the design of cities influences the urban heat island. // Journal of the American Planning Association. 67, (2001), pp. 186-198.

[21] Voogt, J. A. Urban heat island. // Encyclopedia of Global Environmental Change. 3, (2002), pp. 660-666.

[22] Arnfield, J. A. Two decades of urban climate research: a review of turbulence, exchanges of energy and water, and the urban heat island. // International Journal of Climatology. 23, (2003), pp. 1-26.

[23] Voogt, J. A.; Oke, T. R. Thermal remote sensing of urban climates. // Remote Sensing of Environment. 86, (2003), pp. 370-384.

[24] Li, S.; Song, C.; Cao, L.; Zhu, F.; Meng, X.; Wu, J. İmpact of Landscape Structure on surface urban heat islands: A case study of Shanghai, China. // Remote Sensing of Environment. 115, (2011), pp. 3249-3263.

[25] Cheval, S.; Dumitrescu, A. The July urban heat island of Bucharest as derived from Modis images. // Theoretical and Applied Climatology. 96, (2009), pp. 145-153.

[26] Lu, D.; Weng, Q. Extraction of urban impervious surfaces from an IKONOS image. // International Journal of Remote Sensing. 30, 5(2009), pp. 1297-1311.

[27] Tooke, T. R.; Coops, N. C.; Goodwina, N. R.; Voogt, J. A. Extracting urban vegetation characteristics using spectral mixture analysis and decision tree classifications. // Remote Sensing of Environment. 113, (2009), pp. 398-407.

[28] Zhang, Y.; Odeh, I. O. A.; Han C. F. Bi-temporal characterization of land surface temperature in relation to impervious surface area, NDVI and NDBI, using a subpixel image analysis. // International Journal of Applied Earth Observation and Geoinformation. 11, (2009), pp. 256-264.

[29] Weng, Q. A remote sensing-GIS evaluation of urban expansion and its impact on surface temperature in the Zhujiang Delta. // China International Journal of Remote Sensing. 22, (2001), pp. 1999-2014.

[30] Arthur, S. T.; Carlson, T. N.; Ripley, D. A. J. Land use dynamics of Chester County, Pennsylvania, from a satellite remote sensing perspective. // Geocarto International. 15, (2000), pp. 25-35.

[31] Carlson, T. N.; Arthur, S. T. The impact of land use/land cover changes due to urbanization on surface microclimate and hydrology: A satellite perspective. // Global and Planetary Change. 25, (2000), pp. 49-65.

[32] Oke, T. R. City size and the urban heat island. // Atmospheric Environment. (1976), pp. 769-779.

[33] Roth, M.; Oke, T. R.; Emery, W. J. Satellite-derived urban heat islands from three coastal cities and the utilization of such data in urban climatology. // International Journal of Remote Sensing. 10, (1989), pp. 1699-1720.

[34] Voogt, J. A.; Oke, T. R. Effects of urban geometry on remotely-sensed surface temperature. // International Journal of Remote Sensing. 19, (1998), pp. 895-920.

[35] Weng, Q.-H.; Lu, D.-S.; Schubring, J. Estimation of land surface temperature- vegetation abundance relationship for urban heat island studies. // Remote Sensing of Environment. 89, (2004), pp. 467-483.

[36] Lu, Y.; Feng, X.; Xiao, P.; Shen, C. Urban Heat Island in summer of Nanjing Based on TM Data. // Urban Remote Sensing Joint Event. 2009.

\section{Authors' addresses}

Murat Uysal, Assistant Prof.

Afyon Kocatepe University, Faculty of Engineering, Geomatics Engineering,

ANS Campus TR-03200, Afyonkarahisar, Turkey

E-mail: muysa1007@gmail.com

Nizar Polat, Research Assistant

Afyon Kocatepe University, Faculty of Engineering, Geomatics Engineering,

ANS Campus TR-03200, Afyonkarahisar, Turkey

E-mail: nizarpolat@gmail.com 